Journal of History Culture and Art Research

Revue des Recherches en Histoire Culture et Art
Vol. 3, No. 2, June 2014

Copyright (C) Karabuk University

\title{
Sekülerleşmeyi Yeniden Düşünmek: Evrensel Bir Karşılaştırma ${ }^{1}$
}

\author{
José Casanova ${ }^{2}$ \\ Çev.: Selman Yılmaz ${ }^{3}$
}

\section{$\ddot{O} \mathbf{z}$}

José Casanova'nın bu makalesi sekülerleşme hakkında doğru bir yorum yapabilmemiz için onun üç farklı anlamı arasında ayrım yapmak gerektiği üzerine kurulmuştur. Casanova bu farklılıkları Modern toplumlarda dini inanç ve ibadetlerin azalması olarak sekülerleşme, Dinin bireyselleşmesi olarak sekülerleşme, ve Devlet, ekonomi, bilim gibi seküler alanların ayrışması olarak sekülerleşme başlıkları altında toplamaktadır. Makale, Amerika ve Avrupa tipi sekülerleşmenin farklılıklarını ortaya koyarak, sekülerleşme sürecinin evrensel dinamiklerini sorgulamaktadir. ${ }^{4}$

Anahtar kelimeler: Sekülerizm, Sekülerleşme, Modernizm.

${ }^{1}$ Casanova, José (2006). Rethinking Secularization: A Global Comparative Perspective. The Hedgehog Review, $8: 1-2,7-22$.

${ }^{2}$ Prof. Dr. José Casavova. Georgetown Üniversitesi Sosyoloji Bölümü öğretim üyesi. En bilinen eseri Public Religions in the Modern World (1994). Son dönem çalışmaları sekülerleşme, evrenselleşme ve din, göç ve din, ve etnik-dini ve kültürel çeşitlilik konularını içeriyor.

${ }^{3}$ Dr., Ankara Üniversitesi İlahiyat Fakültesi Din Sosyolojisi Anabilim Dalı.

${ }^{4}$ Makalenin özeti çevirene aittir. 


\section{Giriş}

Sekülerleşme hakkında anlamlı bir şekilde konuşabilmemiz için onun üç farklı anlamı arasında ayrım yapmak gerektiğini on yıldan daha uzun bir süre önce önermiştim:

a) Modern toplumlarda dini inanç ve ibadetlerin azalması olarak sekülerleşme, çoğunlukla evrensel, doğal ve gelişimsel bir süreç olarak addedildi. Bu tanım nispeten yeni olmakla birlikte sekülerleşme ile ilgili güncel akademik tartışmalarda en yaygın kullanıma sahiptir. Fakat bu haliyle henüz birçok Avrupa dilindeki sözlüğe girmemiştir.

b) Dinin bireyselleşmesi olarak sekülerleşme, çoğunlukla hem çağdaş tarihi bir eğilim hem de olması gereken bir durum olarak anlaşılmış, hatta modern liberal demokratik siyasetin bir önkoşulu addedilmiştir. ${ }^{5}$

c) (Devlet, ekonomi, bilim gibi) seküler alanların ayrışması olarak sekülerleşme, genel olarak dini kurum ve kurallardan bir "kurtuluş" olarak anlaşılmaktadır. Bu tanım klasik sekülerleşme teorilerinin ana gövdesini oluşturup, bu terimin Ortaçağ Hıristiyanlığ i içindeki etimolojik-tarihsel anlamını ifade etmektedir. Bütün Avrupa dillerindeki her bir sözlük de bu tanıma işaret ederek, kişilerin, varlıkların, anlamların, vb. kiliseye veya dine ait olandan sivil hayata, kullanıma, mülkiyete veya denetime geçişini ifade eder. ${ }^{6}$

Sekülerleşme teorileri arasında bu analitik farkl1lığ sağlamanın, bu üç teorinin geçerliliğinin birbirinden bağımsız olarak incelenmesini sağlayacağını düşünüyorum. Böylece karşılaştırmalı tarih incelemeleri içerisindeki farklı sekülerleşme motiflerini ve bu terimin her üç manasını da içeren, bütün toplumları ve medeniyetleri kapsayan, çoğunlukla faydasız sekülerleşme tartışmalarının üzerinde yeniden düşünülebilecektir. Fakat yine de Avrupalı ve Amerikalı din sosyologları arasındaki tartışmalar hız kesmeden devam edecektir. Klasik teoriyi savunan Avrupalılara göre Batı Avrupa toplumlarının sekülerleşmesi deneysel olarak reddedilemeyecek bir gerçekliktir. ${ }^{7}$ Fakat Avrupalılar sekülerleşmenin geleneksel anlamı ile daha yeni anlamı olan kademeli, özellikle 1960'lardan sonra ifade edildiği şekliyle, kuvvetli ve geri dönülemeyecek bir biçimde dini inanç ve ibadetlerin Avrupa halkı arasında azalacağı görüşleri arasında gidip gelmektedirler. Avrupalı sosyologlar bu iki anlamın öz olarak birbirleriyle

\footnotetext{
${ }^{5}$ Benim kitabım, Public Religions in the Modern World (Chicago: University of Chicago Press, 1994), ampirik ve normatif olarak bireyselleşme tezinin geçerliliğini sorguluyor.

6 "Secularization," The International Encyclopedia of Social and Behavioral Sciences, ed. Neil J. Smelser and Paul B. Baltes (Oxford: Elsevier, 2001) 13,786-91.

${ }^{7}$ Steve Bruce, God Is Dead: Secularization in the West (Oxford: Blackwell, 2002).
} 
bağlantılı olduğu görüşüne yatkındırlar. Çünkü onlar dini kurumların toplumsal önemi ve gücündeki düşüş ile dini inanç ve ibadetlerin bireyler arasındaki azalması olarak özetlenebilecek bu iki gerçekliği, modernleşme sürecinin yapısal bir parçası olarak görüyorlar.

Amerikalı din sosyologları ise sekülerleşme teriminin kullanımını daha dar ve daha güncel manada ele alıp, onu dini inanç ve ibadetlerin bireyler arasında azalması şeklinde kullanmaktadırlar. Onlar toplumun sekülerleşmesini fazlaca sorgulamadan bu durumu dikkat çekici olmayan bir gerçeklik olarak addetmektedirler. Onlara göre, Amerika Birleşik Devletleri zaten modern dünyevi bir toplum olarak meydana gelmiştir. Bu sebeple Amerikan halkının dini inanç ve ibadetlerinde önemli bir düşüşe işaret eden bir kanıt görmemektedirler. Hatta bu konuda tarihsel gerçekler tam tersine bağımsızlığından beri Amerikan nüfusunun kiliseye katılımının arttığını göstermektedir. ${ }^{8}$ Sonuç olarak Amerikalı birçok din sosyoloğu sekülerleşme teorisini veya en azından bu teorinin dini inanç ve ibadetlerde aşamalı bir düşüş olacağını öngören varsayımını bir köşeye atma ve Avrupalı bir efsane olarak görme eğilimindedir. Çünkü sekülerleşmenin alışılagelmiş “işaretleri” olan kiliseye devam, ibadetin sıklığı, Tanrı inancı gibi hiçbir kanıt uzun dönemli bir azalma eğilimi göstermemektedir. ${ }^{9}$

Yeni Amerikan modeli, Avrupa modeli sekülerleşme teorisini geçersiz kılmıştır. ${ }^{10}$ Rasyonel seçim teorisinin aşırı bir ucu olarak “dini pazarın arzı” versiyonunda, Amerikalı sosyologlar, yüksek düzeyde bireysel dindarlık ile din ve kilisenin birbirinden ayrılması, devlet müdahalesinin kaldırılması, rekabete açık ve çoğulcu dini pazarlar arasında yapısal bir bağın olduğunu Amerika örneğini vererek iddia etmektedirler. Böylece sekülerleşme teorisindeki Amerika'nın istisna olduğu varsayımı, şimdi Avrupa'nın Amerikan modelinden bir ayrılma olduğu şeklini almaktadır. Şimdilerde Avrupa'daki düşük seviyeli dindarlık, dini yapılanmadaki veya dini pazardaki aşırı kontrollü tekelci yapıların sürekliliği ile açıklanmaya başlanmıştır. ${ }^{11}$ Fakat, Avrupa içindeki karşılaştırmalı kanıtlar Amerika teorisinin temel argümanlarını

\footnotetext{
${ }^{8}$ Jon Butler, Awash in a Sea of Faith: Christianizing the American People (Cambridge, MA: Harvard University Press, 1990); Roger Finke and Rodney Stark, The Churching of America, 1776-1990: Winners and Losers in Our Religious Economy (New Brunswick: Rutgers University Press, 1992); Andrew M. Greeley, Religious Change in America (Cambridge, MA: Harvard University Press, 1989).

${ }^{9}$ Rodney Stark, "Secularization, R.I.P.," Sociology of Religion 60.3 (1999): 249-73; Rodney Stark and William S. Bainbridge, The Future of Religion (Berkeley: University of California Press, 1985).

${ }^{10}$ R. Stephen Warner, "Work in Progress toward a New Paradigm for the Sociological Study of Religion in the United States," American Journal of Sociology 98.5 (1993): 1,044-93.

${ }^{11}$ Theodore Caplow, "Contrasting Trends in European and American Religion," Sociological Analysis 46.2 (1985): 101-8; Rodney Stark and Laurence Iannaccone, "A Supply-Side Interpretation of the 'Secularization' of Europe," Journal for the Scientific Study of Religion 33 (1994): 230-52; Roger Finke, "The Consequences of Religious Competition: Supply-Side Explanations for Religious Change," Rational Choice Theory and Religion: Summary and Assessment, ed. L. A. Young (New York: Routledge, 1997) 45-65.
} 
desteklememektedir. Polonya ve İrlanda'daki tekelci yapılar yüksek düzeyde bir dindarlık ihtiva ederken, başka ülkelerde artan liberallik ve din kilise ayrışması çoğunlukla düzenli olarak dindarlığın azaldığını gösteren oranlar vermektedir. ${ }^{12}$

Bu tartışma bir kördüğüm haline gelmektedir. Geleneksel sekülerleşme teorisi göreceli olarak Avrupa için uyumlu, fakat Amerika Birleşik Devletleri için değildir. Amerikan modeli Amerika Birleşik Devletleri için göreceli olarak işlerken, Avrupa için işlememektedir. Her iki teori de Avrupa içindeki farklı durumlar için makul bir açıklama getirememektedir. En önemlisi iki teorinin de diğer dünya dinleri ve dünyanın geri kalanı üzerinde iyi bir şekilde işlememesidir. Bu sebeple bu kördügümü aşmak ve bu faydasız tartışmanın üstesinden gelmek için terminolojik ve kuramsal anlaşmazlıklar açık bir şekilde ortaya konmalıdır. Fakat en önemlisi, bütün kategorilerin tarihsel ve kavramsal bağlamlarını çıkarmanın, Avrupa ve Kuzey Amerika dışına ilgiyi çekmenin ve daha evrensel bir bakış açısı benimsemenin gerekliliğidir. ${ }^{13}$

Dini bireyselleşme ve azalma tezleri geçmiş on beş yıl boyunca pek çok eleştiri almış ve revizyondan geçmiş olsa da, sekülerleşmeyi farklı kurumsal alanlarda veya modern toplumların alt sistemlerinde işlevsel ayrışmanın bir süreci olarak gören düşünce biçimi sosyal bilimlerde, bilhassa Avrupa sosyolojisinde, göreceli olarak itiraz görmemiştir. Fakat ayrışmanın çok yönlü ve çeşitli tarihi motifleri ile bir kişinin çağdaş Batı toplumları tarihinde bulacağı devlet ve kilise, devlet ve ekonomi, ekonomi ve bilim gibi çeşitli kurumsal alanların modern işlevsel tanımının etrafında birleştirerek yapılan bir sınıflamanın doğru olup olmadığını sorgulamamız gerekir.

Hatta Batı Avrupa toplumlarındaki ayrışmanın tarihsel sürecinin analitik yapılanmasının, seküler ayrışmayı bütün "modern” toplumların evrensel bir şartı veya normatif bir parçası olarak öne süren genel modernizm teorilerinden bir ayrılma olarak görülüp görülebileceğinin de sorgulanması gerekir. Diğer bir ifade ile, Avrupa'nın tarihi bir parçası olarak sekülerleşme teorisi evrensel modernleşme teorilerinden farklı mıdır? Batılı olmayan, seküler olmayan modernizm var olabilir mi? Seküler ayrışma bir toplumu "modern" olarak ne tanımlıyorsa tam olarak odur önermesinde olduğu gibi, modernizm tanımları kaçınılmaz olarak kendini tekrar mı eder?

Talal Asad'ın, seküler gerçek “insan hayatının kendisini zamanla 'dini' gücün kontrolünden kurtardığı ve dinin pozisyonunu değiştirmeyi başardığı bir alan olarak

\footnotetext{
${ }^{12}$ Steve Bruce, "The Supply-Side Model of Religion: The Nordic and Baltic States," Journal for the Scientific Study of Religion 39.1 (2000): 32-46.

${ }^{13}$ José Casanova, "Beyond European and American Exceptionalisms: Towards a Global Perspective," Predicting Religion, ed. Grace Davie, Paul Heelas, and Linda Woodhead (Aldershot: Ashgate, 2003) 17-29.
} 
düşünülmemelidir” görüşüne kesinlikle katılıyorum. ${ }^{14}$ Avrupa'nın sekülerleşmesinin tarihsel sürecinde, dini ve seküler olan ayrılamayacak şekilde iç içe geçmiş ve aynı derecede birbirlerini etkilemişlerdir. Asad "sekülerleşmenin tarihi sürecinin önemli ideolojik değişimlere yol açtığını... bir zamanlar sekülerin teolojik tartışmaların bir parçası olduğunu” göstermiştir. Daha sonradan "dini” olan, seküler siyasi ve bilimsel tartışmalar tarafından kuşatılmış, böylece evrensel bir konsept ve tarihsel bir kategori olarak “din”, Batılı seküler modernizmin bir parçası olarak ortaya çıkmıştır. ${ }^{15}$

Fakat Asad'ın seküler soy araştırması, onun güzel bir sekilde ortaya çıkardığı, sekülerizmin kendi soy araştırmalarına aşırı bağımlıdır. Ayrıca Asad sekülerin oluşumunun, sözüm ona Papalığın Dönüşümünden Protestan Reformu'na, on yedi ve on sekizinci yüzyıllardaki sofu ve dindar tarikatlarından on dokuzuncu yüzyıl Amerika'sındaki mezhepsel Protestanlığa kadar, Avrupa Hıristiyanlığının içsel dönüşümü ile ayrılmaz şekilde ilgili olduğunun farkına varamamıştır. Bu değişimler Batı Hıristiyanlığının içsel sekülerleşmesinin bir süreci olarak mı, veya seküler aklın bir marifeti olarak mı, yoksa her ikisini de içerecek şeklinde mi tarif edilmelidir? Sekülerleşmenin yeniden düşünülmesi birleşme ve ayrışmadaki değişik oluşumlar ile onların bütün dünya dinlerindeki ortak noktalarının ciddi şekilde incelenmesini gerektirir.

Kategorilerin oluşturulması Batı Avrupa'nın gelişimindeki belli Hıristiyan tarihsel gerçeklikleri ile Avrupalı ve Batılı toplumlardaki sekülerleşme ve ayrışmanın bir çok ve çeşitli tarihsel formlarının olduğunun farkına varılması ile başlamalıdır. $\mathrm{Bu}$ çeşit bir tanıma, sekülerleşme ve ayrışmanın formlarını diğer medeniyetler ve dünya dinleri üzerinde incelerken daha az Avrupa-merkezli bir karşılaştırma yapmayı, ve daha da önemlisi, evrenselleşme sürecinin Avrupa'nın sömürgeci genişlemesinin bir yansıması olarak, bütün bu gelişimlerin dinamik bir şekilde ilgili ve ortaklaşa oluşturulduğunun farkındalığını artırır.

\section{Çok Yönlü Ayrışımlar, Sekülerleşmeler ve Moderniteler}

Batı'da çok yönlü ve çeşitli sekülerleşme tipleri ve çok yönlü ve çeşitli Batılı moderniteler var. Bunlar hala Katolik, Protestan, Ortodoksluk arasındaki ile Lutheran ve Kalvinist Protestanlık arasındaki temel tarihsel farklılıklarla ilişkilidir. David Martin'in işaret

\footnotetext{
${ }^{14}$ Talal Asad, Formations of the Secular: Christiantiy, Islam, Modernity (Stanford: Stanford University Press, 2003) 191.

${ }^{15}$ Asad 192; see also Talal Asad, Genealogies of Religion (Baltimore: The Johns Hopkins University Press, 1993).
} 
ettiği gibi, Latin-Katolik kültürel dünyasında, ve daha geniş olarak Avrupa kıtasında, din ve ayrışmış seküler alanlar ve Katolik Hıristiyanlık ile modern bilim, modern kapitalizm ve modern devlet arasında bir çatışma vardı. ${ }^{16}$ Bu müzmin çatışmanın bir sonucu olarak, Aydınlanmanın din eleştirisi burada kendine büyük bir yankı buldu. Modernizmin sekülerci incelemesi, aklın, özgürlüğün ve dünyevi arzuların dini kısıtlamalardan kurtuluşunun bir zaferi olarak inşa edildi. Fransa İhtilali'nden günümüze, “ilerlemeci” Avrupalı her sosyal hareket pratikte sekülerizm tarafından dizayn edildi. Sekülerleşme ve ayrışmanın işlevselci teorilerini oluşturan bu sekülerci öz-anlatımlar, henüz yeni ayrışmaya başlamış dini alanın çoğunlukla yıkılması ve sınırlandırılması pahasına, bu süreci seküler alanların genişlemesi ve kurtulması adına tasavvur ettiler. Sınırlar iyi korundu, sadece yeniden dizayn edildiler ve dini dramatik bir şekilde bireysel alana ve kenarlara ittiler.

Anglo-Protestan kültür dünyasında ve özellikle Amerika Birleşik Devletleri’nde, din ve seküler olarak ayrışmış alanlar arasında "gizli bir anlaşma" vardı. Amerikan Protestanlığı ve kapitalizm arasında bir gerilime işaret eden tarihi çok az kanıt vardır. Aynı şekilde on dokuzuncu yüzyıl sonlarındaki Darwin krizinden önce Amerika Birleşik Devletleri'nde din ve bilim arasında çok az bir gerginlik vardı. Amerikan Aydınlanması çok düşük seviyede din karşıtı özellikler barındırıyordu. Hatta Anayasa'nın ilk değişsikliği olan, “din ve devletin ayrışmasını” getiren çift taraflı ibare, federal devleti herhangi dini bir bağlılıktan korumayı amaçladığı kadar, "dinin özgürce yaşanabilmesinin" önünde devletin bir dahlinin olmasını da engelleme amacındaydı. Amerika'daki "yenilikçi” sosyal hareketlerin son zamanlara kadar ancak nadiren "sekülerci" değerlere sarıldığı, hatta İncil ve "Hıristiyanlık" değerlerine başvurunun Amerikalı sosyal hareketlerde ve Amerikalı başkanların konuşmalarında şüphesiz daha yaygın olduğu görülmektedir.

$\mathrm{Bu}$ karşılaştırmanın amacı meşhur Amerikan toplumunun daha "dindar" ve böylece Avrupa toplumlarından daha az "seküler" olduğu gerçeğine vurgu yapmak değildir. İlk önerme belki doğru olabilir ama ikincisi için böyle bir durum söz konusu değildir. Hatta tersine, Amerika Birleşik Devletleri daima modern seküler ayrışmış toplumun örnek bir biçimi olmuştur. Öyle ki “sekülerliğin” zaferi dine rağmen değil, dinin yardımıyla gerçekleşmiştir. Sınırların belirginliği kaybolmuş ve nerede sekülerin bittiği nerede kutsalın başladığı, en azından Avrupa kilise standartlarına göre, açık değildir. Tocqueville'nin gözlemlediği gibi, “Amerikalılar dinlerini sadece kişisel ilgilerinin bir sonucu olarak takip etmezler, hatta daha sık olarak, icra ettikleri bu ilgiyi dünya hayatının içine yerleştirirler”. ${ }^{17}$ Bütün bunlara rağmen, Amerika Birleşik

\footnotetext{
${ }^{16}$ David Martin, A General Theory of Secularization (New York: Harper \& Row, 1978).

${ }^{17}$ Alexis de Tocqueville, Democracy in America (New York: Harper \& Row, 1965) 284.
} 
Devletleri'nin fonksiyonel olarak daha az ayrışmış bir toplum ve böylece Fransa veya İsveç'den daha az modern ve seküler olduğunu tartışmak gülünç olur. Hatta tersine, devletçi Fransa'nın devlet, ekonomi, bilim, vb. alanlarında Amerika Birleşik Devletleri’nden daha az işlevsel ayrışmaya sahip olduğu tartışılabilir. Fakat bu durum Fransa'yı Amerika Birleşik Devletleri'nden ne daha az modern yapar ne de daha az seküler.

Amerikalı din sosyologları dar görüşlü bir bakış açısıyla sekülerleşmenin bir Avrupa efsanesi olduğunu söylediklerinde, sadece Amerika Birleşik Devletleri'nin modern seküler bir devlet olması ve Avrupalı din ve devlet başkanlıklarının tek kişide toplandığı mutlakiyetçi devletin resmi kilisesi tecrübesini yaşamadıkları ve modern seküler bir toplum olmak için Avrupalı bir seküler ayrışma sürecinden geçmeye ihtiyaç duymadıkları konularında haklıdırlar. Sekülerleşmenin Avrupa konsepti "Hıristiyan” Amerika Birleşik Devletleri için özellikle ilgili bir kategori sunamıyorsa, çok farklı seküler ve dini yapılar arz eden diğer medeniyetler için çok daha az bir şekilde doğrudan uygulanabilir. Tarihi süreci analitik olarak kavramlaştırırsak, sekülerleşme Ortaçağ'dan günümüze Batı Avrupa Hıristiyanlığının değişimindeki içsel ve dışsal faktörlerin bir arada değerlendirildiği bir kategori olarak anlam kazanmaktadır. Fakat ne zamanki bu kategori toplumsal gelişmenin evrensel bir parçası olarak genelleştirilince veya diğer dünya dinleri ve medeniyetleri üzerinde de uygulanınca sorunlu hale geliyor. Öyle ki bunlar din ve dünya veya kozmolojik aşkınlık ve dünyevi içkinlik arasındaki ilişki ve sorunlarında oldukça farklı yapısal dinamikler gösteriyorlar.

Sekülerleşme kategorisi mesela Konfüçyüsçülük veya Taoizm gibi "dinler" üzerinde zorlukla uygulanabilir. Şu kadarki onlar "dünya" ile aralarındaki bağlantıda yüksek bir gerilime sahip olmalarıyla nitelendirilmemişlerdir ve kilise benzeri bir yapıları bulunmamaktadır. Öyleyse onların aşkınlık modeli güçlükle "dini" olarak adlandırılabilir. Bu durumda, bu "dünyevi" ve "yumuşak" dinlerin bir sekülerleşme süreci altına girmelerine gerek yoktur. "Dünyevileşme" veya "dine aidiyetten sivil kullanıma geçiş" olarak sekülerleşme medeniyet bağlamında fazla bir anlam ifade etmemektedir. Bu itibarla, Çin ve Konfüçyüs medeniyet bölgesi "seküler" at başıdır. Modernleşme ve sekülerleşme arasındaki doğal ilişki varsayımı oldukça problemlidir. Amerika Birleşik Devletleri gibi seküler fakat oldukça dindar modern toplumlar olabileceği gibi, bizim Avrupa merkezli bakış açımızdan oldukça seküler ve din karşııtı görülen Çin gibi modern dönem öncesi toplumlar olabilir. ${ }^{18}$

\footnotetext{
${ }^{18}$ Nasıl A.B.D. sanayi-sonrası gelişmiş toplumlarda "aykırı" ve "olağan dıșı" olarak görülüyorsa, benzer şekilde Çin'de tarımsal toplumlar arasında aykırı olarak duruyor. Aslında, Çin'in dini inançları ve dini katılımı dünyadaki her ülkeden daha düşük seviyede açığa vurması, güvensizlik/beka esasları ile dini inanç ve katılım arasında ilişkinin olduğunu varsayan görüşe meydan okuyor. Norris/Inglehart ölçeğinde, tarımsal Çin —en azından oradaki Konfüçyüsçü elitler - yüzyıllar boyunca oldukça yüksek seküler-rasyonel bir toplum olarak ortada olurdu. Bakınız
} 
Avrupa sömürgeciliğinin genişlemesi ve bunu takiben kapitalizmin, Avrupa devlet sisteminin, modern bilimin ve modern seküler fikirlerin dünya geneline yayılmasıyla özellikle Hıristiyan Batı Avrupa’ya özgü sekülerleşme dinamikleri evrenselleşmiştir. Bu durumda ilgili sorular, Konfüçyüsçülük, Taoizm ve diğer dünya dinleri Batılı seküler modernitenin evrensel genişlemesine nasıl karşılık vermişlerdir ve bütün dini gelenekler bu evrensel zorluğa karşılık vermek için nasıl yeniden yorumlanmışlardır olmaktadır.

İlk olarak S. N. Eisenstadt tarafında geliştirilen çok yönlü moderniteler terimi hem kavram hem de modern evrensel trendlerin pragmatik görünümü olarak, seküler kozmopolitlik veya medeniyetler çatışması terimlerinden daha uygun bir kavramsallaştırmadır. $\mathrm{Bu}$ tanım su götürmez şekilde her iki kavramdan taraflar barındırmaktadır. Kozmopolitizmde olduğu gibi çok yönlü moderniteler terimi bütün "modern" toplumların onları "geleneksel” veya modern öncesi formlarından ayıran ortak noktalar veya karakteristik özellikler barındırmasını içerir. Fakat bu özellikler veya ilkeler çeşitli şekiller ve farklı kurumsallaşmalar ihtiva eder. Hatta bu kurumsallaşmaların bir çoğu geleneksel tarihi medeniyetlerin bir devamıdır veya onlarla uyumludur. Böylece, hem modernliğin medeniyetleşmesi hem de modern öncesi tarihi medeniyetlerin, çok yönlü moderniteleri şekillendiren çağdaş koşullar altında devamlı değişimi vardir.

Modern karakteristik özelliklerin bir çoğu Batı'da ortaya çıkmış olsa da, burda bile çok yönlü modernitelere rastlanır. Doğal olarak, bu modern karakteristik özellikleri kazanan ve kurumsallaştıran batılı olmayan toplumlar ve medeniyetlerde bu çeşitlilik daha belirgin hale gelir. Dahası, modern özellikler ille de geleneğin pahasına veya onun zıddı olarak gelişmekten ziyade, geleneğin dönüşmesi ve pragmatik olarak düzenlenmesi ile gelişirler. Bu itibarla, çok yönlü moderniteler fikri medeniyetler çatışması fikri ile beraber, çok yönlü modernitelerin oluşması için kültürel geleneklere ve dünya dinlerine vurgu yapar.

Seküler kozmopolitlik hala seküler modernite ve kutsal gelenek arasında biri artınca diğerinin azalacağını varsayan katı bir zıtlık üzerine kurulmuştur. Tersine, medeniyetler çatışması öngörüsü gelenek ve modernite arasında zorunlu bir devamlılı̆ga vurgu yapar. Batı modernitesi, Batı geleneğinin bir devamı olarak algılanmıştır. Buna göre, diğer medeniyetler de modernleştikçe daha fazla Batı'ya benzeyecekler ve onlar da kendi geleneklerinin devamlılığını sağlayacaklardır. Bu şekilde, bütün modern toplumlar genel olarak kendilerinin çeşitli ve çoğunlukla kıyaslanamaz geleneklerini masaya getirerek kaçınılmaz medeniyetler çatışmasına neden olacaklardır.

Figür: 10.1 and 10.2 in Pippa Norris and Ronald Inglehart Sacred and Secular: Religion and Politics Worldwide (Cambridge: Cambridge University Press, 2004) 224-6. 
Çok yönlü moderniteler fikri gelenekle modernin radikal bir kırılma yaşayacağ fikrini reddettiği gibi, geleneğin esas olarak modern bir biçimde devam edeceği fikrini de reddeder. Bütün gelenekler ve medeniyetler modernleşme sürecinde radikal olarak değişime uğrasa da, onlar modern özelliklerin kurumsallaşmasını belli yollarla düzenleme olasıllı̆ına sahiptirler. Gelenekler modern şartlara cevap verip uyum göstermeye zorlanmışlardır. Modern durumlar için gelenekleri yeniden düzenleme süreci onların ayrıca modernitenin belli formlarını düzenlemesine yardımcı olmuştur.

\section{Dini Azalma, Canlanma veya Değişim?}

Kurumsal Hıristiyanlığın Avrupa'da tedrici düşüşü inkar edilemez sosyal bir gerçekliktir. 1960'lardan beri, göreceli olarak yüksek düzeylerde bireysel dindarlık devam etse de, Avrupa nüfusunun artan bir şekilde çoğunluğu geleneksel dini uygulamalara düzenli bir şekilde katılmayı bırakmıştır. Grace Davie Avrupa'daki bu genel durumu "aidiyetsiz inanç" şeklinde nitelendiriyor. ${ }^{19}$ Aynı zamanda, Avrupalıların büyük çoğunluğu, en seküler ülkelerdekiler bile, zımni, yaygın ve gizli Hıristiyan kültürel kimliğine işaret ederek kendilerini hala "Hıristiyan" olarak tanımlıyorlar. Danièle Hervieu-Léger Avrupa'nın bu zıt karakterini "inançsız aidiyet" olarak isimlendiriyor. ${ }^{20}$ Fransa'dan İsveç'e, İngiltere'den İskoçya'ya tarihi kiliseler (Katolik, Lutheran, Anglikan veya Kalvinist) aktif üyelerden yoksun olsalar da, halk ulusal dinlerini taşıyormuşçasına, hala dolaylı olarak faaliyet gösteriyorlar. Bu bakımdan, bir çok Avrupalı arasında, "seküler" ve "Hıristiyan" kültürel kimlikleri kompleks ve nadiren dile getirilen bağlar içinde iç içe geçmiştir.

Yine de Avrupa'nın sekülerleşmesini artan akılcılık, kurumsal ayrışma veya bireyselcilik referansları ile ifade eden geleneksel açılamaları, Amerika Birleşik Devletleri gibi diğer modern toplumlar aynı seviyelerde bir dini azalma göstermediği için ikna edici değildir. Avrupa'daki dini gelişmelerin istisnai karakteri fark edildiğinde, modernleşmenin genel sürecini araştırmak yerine, özellikle Avrupa'daki tarihi gelişmeleri araştırmak gerekli hale geliyor. Gerçekten, sosyolojik olarak en ilgi çekici konu 1950'lerden bu ana Avrupa nüfusu arasındaki sürekli dini düşüş gerçeği değil, bilakis, dini azalmanın sekülerleşme modeli yoluyla yorumlanması ve böylece "sekülerci" bir anlayışla azalmayı "normal" ve "gelişimsel” olarak yorumlayan yarı

\footnotetext{
${ }^{19}$ Grace Davie, Religion in Britain since 1945: Believing Without Belonging (Oxford: Blackwell, 1994); and Religion in Modern Europe: A Memory Mutates (Oxford: Oxford University Press, 2000).

${ }^{20}$ Danièle Hervieu-Léger, "Religion und Sozialer Zusammenhalt in Europa," Transit: Europäische Revue 26 (Summer 2004): 101-19.
} 
normatif bir sonuç olarak "modern" ve "aydınlanmış" Avrupa sonucuna ulaşılmasıdır. Batı Avrupa toplumlarının sekülerleşmesi sosyo-ekonomik gelişmelerin yapısal yönleri ile açıklanabileceğinden ziyade, sekülerizmin bilgi sisteminin başarısı şeklinde daha iyi açıklanabilir. Hatta Avrupa'daki dahili farklılıklar da din-devlet ve din-millet ilişkilerinin tarihi şekilleriyle ve aynı şekilde, modernleşme seviyesi yerine, Hıristiyanlığın farklı kolları arasında sekülerleşmenin farklı yollar alması şeklinde daha iyi bir biçimde açıklanabilir

Bu konulardaki eğilimin, sekülerleşme sürecini sosyal (kilise, devlet ve millet), siyasal ve dini toplulukların kaynaşması ve parçalanması biçimlerine ilişkilendirmek yerine, modernleşme süreci ile ilişkilendirmek şeklinde olması, sekülerleşme tartışmasındaki ayağımızdaki kördüğümdür. Weber'in izinde, analitik olarak topluluk kültü ve kurtuluşçu dini toplulukları ayırmalıyız. ${ }^{21}$ Bütün kurtuluş dinleri, bölgesel bir siyasi topluluğu kapsayan veya sosyal bütünleşmenin Durkheim'ci işlevini yerine getiren, topluluk kültü olarak fonksiyon göstermez. Amerika'daki bir çok mezhep, cemaat veya kültün esasen bireysel kurtuluş dinleri olarak fonksiyon göstermesi buna örnek gösterilebilir. Ayrıca, her topluluk kültü de bireysel kurtuluş dini gibi fonksiyon gösterip bireylere hastalıktan, yoksulluktan ve her türlü stres ve tehliken kurtulmayı sunmaz. Örnek olarak Çin'deki devlet Konfüçyüsçülüğü, Japonya'daki Şintoizm veya din ve devlet başkanının aynı kişide toplandığı imparatorluk kültleri düşünülebilir. Daha küçük dini "halk" formları kişisel kurtuluş ve iyileşme sağlama eğilimindedirler.

Oldukça farklı olmakla beraber, Hıristiyan kilisesi ve İslam ümmeti dini ve bireysel kurtuluş dinleri ile toplumsal kültlerin tarihsel kaynaşmasına iki örnektir. Avrupa'daki gerçek kafa karıştırıcı soru ve Avrupa'nın sekülerleşmesinin istisnai özelliğinin hesaplanmasındaki açıklayıcı anahtar, neden ulusal kiliselerin kendilerinin, kollektif hafızanın taşıyıcısı ve zihnen var edilmiş ulusal toplulukların müşterek temsilcisi olan, topluluk kültü şeklinde fonksiyon gösteren geleneksel tarihi rollerini seküler ulus devletlere devrettiği ve bireysel kurtuluş dinleri olarak faaliyet gösteren yeteneklerini bu süreçte kaybettiği sorularıdır. Diğer bir önemli soru da, neden Avrupa'daki bireyler kendi ulusal kiliselerine olan inançlarını kaybettiklerinde alternatif kurtuluş dinleri aramaya yönelmediler sorusudur. Kesinlikle buradaki cevap, Avrupalıların, açık bir şekilde terk etmiş olsalar bile, kendi ulusal kiliselerine olan bağll1ıklarının örtülü bir biçimde sürmesidir. Ulusal kiliseler orada doğum, ölüm ve diğer önemli kişisel değişimlerdeki dinsel törenleri yönetme zamanlarında ulaşılabilmek için halk yararına varlıklarını sürdürmüşlerdir. $\mathrm{Bu}$ özel durum Avrupa'da gerçek bir rekabetçi dini pazarın yokluğunu ve buna olan isteğin azlığını açıklamaktadır.

\footnotetext{
${ }^{21}$ Max Weber, "The Social Psychology of the World Religion," From Max Weber, ed. H. H. Gerth and C. Wright Mills (New York: Oxford University Press, 1946) 272.
} 
Bu durumun tersine, Amerika Anayasası'nın ilk değişikliğinde çift taraflı ibare şeklinde kodlanmış olan kilise ve devletin ayrılmasındaki özel durum Amerika'daki dini çoğulculuğun eşsiz durumunu kurmaya hizmet etmiştir. Amerika Birleşik Devletleri hiçbir zaman ulusal bir kiliseye sahip olmamıştır. Zamanla, Amerika'daki bütün dinler, kiliseler ve cemaatler, kökenleri, doktrinsel iddiaları ve dini kimlikleri fark etmeksizin "mezheplere" dönüşmüşler, resmi olarak anayasanın altında eşit olarak ve görece özgür, çoğulcu ve gönüllü dini pazarda rekabet etmişlerdir. Organizasyon şekli ve bu çeşit bir dini sistem ilkesi ile mezhepçilik büyük Amerikan dini keşfini oluşturmaktadır. ${ }^{22}$ Farklılıklarına rağmen ayrı ayrı ve bütün mezhepler Amerikan sivil dini ile beraber ulusun toplumsal kültü olarak fonksiyon göstermektedir.

İlk başta, çeşitlilik ve genel eşitlik Amerikan Protestanlı̆̆ içinde dahili mezhepsel bir dini çoğulculuk olarak inşa edilmişti. Amerika, "Hıristiyan'ın" sadece "Protestan" anlamına geldiği "Hıristiyan" bir millet olarak tanımlandı. Fakat nihayetinde, çoğunlukla Katolik göçmenlere yöneltilen Protestan ulusalcılığının uzun süreli infiallerinden sonra, bu yapı Katolik ve Yahudi gibi diğer din mensuplarının Amerikan dini çoğulculuk sistemine entegre olmasına izin verdi. Amerikan dini ve milleti bu süreçte eşit şekilde değişirken, çifte uyum sürecinin işlemesiyle Katoliklik ve Yahudilik Amerikan dinleri haline geldi. Amerika, "MuseviHıristiyan" bir millet haline gelirken, Protestanlar, Katolikler ve Yahudiler Amerikan sivil dininin üç mezhebini oluşturdular.

Avrupalı göçmenlerin birleşme sürecinde dinin, dini kurumların ve dini kimliklerin merkezi bir rol oynadıkları gerçeği bolca belgelenmiş ve Will Herberg'in çok iyi bilinen tezinin merkezini oluşturmuştur. ${ }^{23}$ Herberg'in, göçmenler Amerikalı oldukça dindarlaştılar iddiası Amerika'daki göçmen dinleri hakkındaki günümüz çalışmalarının bir çoğunda yeniden ifade edilmektedir. ${ }^{24}$ Böylece şunun farkına varmak gerekir ki, göçmen dindarlığı basit bir geleneksel tortu değildir. Eski Dünya yaşamı, Yeni Dünya'ya uygun bir karşılık verme yerine, muhtemelen yeni duruma adaptasyon ile ortadan kaybolur. Bu tez sadece göçmenlerin belli bir sosyal baskıdan dolayı Amerikan dini normlarına uyum sağladığına işaret etmez, ki bu durum şüphe getirmez bir gerçek, fakat daha da önemlisi, bu müşterek dini kimliklerin Amerika tarihinde

\footnotetext{
${ }^{22}$ Sydney E. Mead, "Denominationalism: The Shape of Protestantism in America," The Lively Experiment: The Shaping of Christianity in America (New York: Harper \& Row, 1976); Andrew M. Greeley, The Denominational Society: A Sociological Approach to Religion in America (Glenview: Scott, Foresman, 1972).

${ }^{23}$ Will Herberg, Protestant-Catholic-Jew (Garden City: Doubleday, 1960).

${ }^{24}$ Bakınız José Casanova, "Immigration and the New Religious Pluralism: A EU/US Comparison," The New Religious Pluralism and Democracy, ed. Thomas Banchoff (New York: Oxford University Press, forthcoming).
} 
dahili sosyal çoğulculuğu sağlayan ana yollardan birisi olduğuna işaret eder. ${ }^{25}$ Bana göre bu tez, Amerika'daki dini canlılığın açıklanmasında rekabetçi dini pazarlardaki rasyonel seçim/dinin arzı teorilerinden daha makul bir tez sunmaktadır.

Hem Avrupa'daki seküler gelişmelerin hem de Amerika'daki dini gelişmelerin nispeten özgün ve istisnai oldukları düşünülebilir. Bu bakımdan herhangi birisi, nasıl Avrupalılar onlarca yıldır yaptıysa, kesin bir şekilde "Amerikan istisnasından” bahsedebilirdi. Veya bugün bir moda haline geldiği şekliyle “Avrupa istisnasından” bahsedebilirdi. Fakat, eğer geçmişte olduğu gibi, Amerika, sekülerleşmenin Avrupa'daki kurallarına bir istisnaydı diye vurgulanırsa; veya bugün sık sık olduğu gibi, seküler Avrupa aşağı yukarı evrensel dini bir canlanmanın istisnası olarak vurgulanırsa, her iki kategori de hayli problemli olur. ${ }^{26}$ Sira dine gelince evrensel bir kural yoktur. Avrupa'nın sömürgeci yayılma zamanı boyunca olduğu gibi, bugün bütün dünya dinleri evrenselleşme ve modernleşme süreçleri tarafından radikal olarak dönüştürülüyorlar. Fakat bu dönüştürmenin bir çok ve çeşitli yollarla olduğu vurgulanmalıdır.

Bütün dünya dinleri asrileşmenin çeşitli süreçlerinden geçerken ve ortaya çıkan dini global sistem içinde birbirleriyle rekabet ederken, modernitenin evrensel yayılmasına ve dinlerin ortak ve karşılıklı sorunlarına cevap vermek zorunda bırakılmıştır. Evrenselleşme koşulları altında dünya dinleri sadece kendi geleneklerini değil aynı zamanda artan şekilde birbirlerinin geleneklerini de kullanmışlardır. Medeniyet içi karşı karşıya gelmeler, kültürel taklitler ve ödünç almalar, diasporal yayılmalar, melezlik, dilin melezleşmesi ve kültürler arası karışımlar, bunların hepsi evrenselliğin parça ve bölümleridir.

Din sosyologları dinin gerilemesi ile daha az takıntılı olmalı ve yeni formlara uyum sağlamalıdırlar. Bütün dünya dinlerini varsayarak, bu formları oluşturan din üç farklı seviyede analiz edilebilir: bireysel seviye, grup seviyesi ve toplumsal seviye. Ernst Troeltsch'in "bireysel mistisizm", "cemaat" ve "kilise" şeklindeki üç çeşit din tanımı yukarıdaki üç seviyeli analiz ile uyumludur. ${ }^{27}$ Bireysel seviyede, Troeltsch ve William James’in geçen yüzyılın başındaki bireysel mistisizm ile ilgili öngörüleri yeterince tuttu. ${ }^{28} 1960$ 'larda Thomas Luckmann'ın

\footnotetext{
${ }^{25}$ Radikalleşme Amerika tarihinde dahili toplumsal çoğulculuğu sağlamanın başlıca diğer bir yoluydu. Herberg'in çalışması işaret ettiği gibi, sadece din değil, sadece ırk değil, günümüz göç çalışmalarının gösterdiği gibi din, ırk ve onların kompleks bağları Amerikan tecrübesinin göçmen katılımını kurmaya hizmet ettiler. Gerçekten bunlar "Amerikan istisnasının" anahtarlarıdır.

${ }^{26}$ Grace Davie, "Europe: The Exception that Proves the Rule?” The Desecularization of the World, ed. Peter Berger (Washington, DC: Ethics and Public Policy Center, 1999).

${ }^{27}$ Ernst Troeltsch, The Social Teachings of the Christian Churches (New York: MacMillan, 1931).

${ }^{28}$ William James, Varieties of Religious Experience (Cambridge, MA: Harvard University Press, 1985); and Charles Taylor, Varieties of Religion Today: William James Revisited (Cambridge, MA: Harvard University Press, 2002).
} 
"görünmez din" olarak adlandırdığı tanım, bireysel dinin dominant formu olarak duruyor ve muhtemelen artan bir evrensel önem kazanacaktır. ${ }^{29}$ Modern birey, anlam sistemlerinin geniş bir düzenlemesinden titizlikle seçmede ayıplanıyor. Batılı bir tek-tanrıcı bakış açısından, çok tanrıcı ve çok bakışlı bireysel özgürlük gibi bir durum oldukça yeni ve postmodern olarak görülebilir. Fakat Batılı olmayan, özellikle Asyalı tümtanrıcı dini gelenekteki bir bakış açısından aynı durum eski durumların bir benzeri olarak görülebilir. Bireysel mistisizm Hindu, Budist ve Taoist geleneklerde, en azından elitler ve dini virtüözler için, devamlı önemli bir seçenek olmuştur. Inglehart'in post-materyal manevi değerlerin genişlemesi sözü bu açıdan, çoğu dini gelenekte şimdiye kadar sadece elitlere ve dini virtüözlere açık olan seçeneklerin genelleştirilmesi ve demokratikleştirilmesi olarak anlanabilir. Bin yıldır elitlerin kullanımındaki imtiyazlı maddi koşullar tüm topluma yayılınca, genellikle onlar için ayrılmış manevi ve dini seçeneklere de aynısı oldu. Ben bu çeşit bir gelişmeyi dini azalma olarak nitelendirmezdim. Fakat kesinlikle günümüz dünyasında yeni olan, en "ilkelinden" en "modernine”, çoğunlukla kendi zamansal ve mekânsal bağlamlarından koparılmış, esnek ve köktenci bireysel kullanım için hazır olan, bütün dünya dinlerinin ve kültürel sistemlerinin aynı anda var ve ulaşılabilir olmasıdır.

Dini gruplar seviyesinde sosyolojinin çoğu, modernleşmenin olumsuz sonuçlarından biri olarak birliğin kaybına yas tuttu. Hem bireysellik hem de toplumsallaşmanın grubun pahasına genişleyeceği düşünüldü. Modernleşme teorileri gelenek ve modernitenin, birlik ve ortaklığın basit ayrılıklarına dayandırıldı. Çoğu sekülerleşme teorisi aynı basit ikili ayrılıklar ve nihayetinde modern toplumsal rasyonalleşmenin uzun zaman sürecinde cemaati yaşamaz yaptığı varsayımı üzerine kurulmuştur. Fakat gerçek şudur ki, Tocqueville'nin açık şekilde gördüğü gibi, modernite her türlü gönüllü birliğin cemaatlerinin inşası ve özellikle yeni dini grupların gönüllü cemaatler olarak inşası için yeni ve genişletilmiş olanaklar sunmaktadır. Tabiki mezhep, gönüllü dini cemaatlerin pragmatik bir şeklidir. Fakat geleneksel teoride, mezhep toplumun geri kalanı ile yüksek ve eninde sonunda sürdürülemez bir gerginlik yaşar. Amerikan mezhepçiliği, tersine, gönüllü dini birliklerin mezhep ilkesinin genelleştirilmesi ve yumuşaması şeklinde anlaşılabilir.

"Kült", "yeni din" veya "yeni dini hareket" diye adlandırılan yapıların çoğu gönüllü cemaat formu üstlenirler. Bu yapılar ayrıca Latin Amerika'daki Hiristiyan bazlı cemaatler veya dünya genelindeki Pentakostal kiliseler gibi, Hıristiyanlığın çoğu dinamik yapısını üstlenirler. Veya on dokuzuncu yüzyılın başlarındaki Amerikan Metodizm'ine benzeyen evanjelik İslam'ın bir çeşidi olan Cemaat-i Tebliğ gibi, İslam'ın en dinamik formlarını ve Sufi tarikatlarının birçok formlarını üstlenirler. Hatta cemaatçilik geleneğinin az geliştiği Hinduizm ve Budizm gibi dünya

\footnotetext{
${ }^{29}$ Thomas Luckmann, The Invisible Religion: The Problem of Religion in Modern Society (New York: Macmillan, 1967).
} 
dinleri, özellikle göçmen bölgelerinde, önemli yeni kurumsal formlar ortaya çıkarmaktadırlar. Göçmen bölgelerindeki bu kurumsal dönüşüm sonuç olarak anavatanlardaki dini kurumların yapısını da önemli bir şekilde etkilemektedir.

Toplumsal seviyede, "muhayyel dini cemaatler" olarak adlandırılabilecek seküler milliyetçilik ve ulusal "sivil dinler" müşterek kimlikleri taşımada önemli olmaya devam edeceklerdir. Fakat, evrenselleşen ulus-ötesi muhayyel dini topluluklarda olduğu gibi, devam eden evrenselleşme süreci muhtemelen büyük "dünya dinlerinin” tekrar ortaya çıkmasını sağlayacaktır. Yeni kozmopolit ve ulus-ötesi muhayyel topluluklar ortaya çıkarken, en ilgili olanların yine eski medeniyetler ve dünya dinleri olması muhtemeldir. Burada Samuel Huntington'un tezi ortaya çıkıyor. ${ }^{30}$ Fakat onun, medeniyetleri, ulus devletleri ve süper güçleri andıran, bölgesel birimler olarak gösterdiği jeopolitik kavramı sorunludur. Bu durum onu gelecekteki evrensel sorunların medeniyetler çizgisinde olacağı öngörüsüne götürmüştür. Aslında, evrenselleşme, büyük dünya dinleri için sadece kendilerini ulus devletin neden olduğu bölgesel kısıtlamalardan kurtarma ve tekrar ulus ötesi boyutları geri kazanma için büyük bir firsat sunmuyor, ama aynı zamanda, büyük bir tehdit getiriyor. Öyle ki, evrenselleşme bir tehdit olarak, bütün kültürel sistemlerin bölgelerini kaldırmayı içeren ve bütün medeniyetleri ve dünya dinlerini tanımlayan sınırlar, insanlar ve tarihler arasındaki ana bağları çözmeyi içeren bir sistem içeriyor.

\section{Dini Bireyselleşme, Dini Kamusallaşma veya Her İkisi?}

Modern otoriter rejimlerin veya modern liberal demokratik sistemlerin her ikisinin de sonunda dini özel alana göndermede başarılı olması mümkün değil. Otoriter rejimler dinin bireyselleşmesini zorlamada belki baskıcı yöntemlerle geçici olarak başarı sağlayabilirler. Dini azınlıklar üzerinde seküler çoğunluğun tiranlığı hariç, demokratik rejimlerin, tersine, böyle bir şey yapmada daha büyük zorluklarla karşılaşmaları muhtemeldir. Fransa örneği gösterdiği gibi, laiklik, vatandaşların çok büyük bir çoğunluğu tarafından oluşturulan bir konsensüs ile, gerçekten devamlı olarak kutsanmış bir esas halini alabilir. Bu vatandaşlar kamu alanlarındaki "görünen dini sembollerin" ulusal geleneklere ve ulusal sisteme bir tehdit olarak değerlendirilmesinden ötürü yasaklanması hükmünün uygulanmasını destekleyebilirler. Açık şekilde Amerika Birleşik Devletleri'nde bu durum tersinedir. Burada seküler azınlıklar ulusal cumhuriyetin Musevi-Hıristiyan tanımlarından dolayı tehdit edilmiş hissedebilirler.

\footnotetext{
${ }^{30}$ Samuel P. Huntington, The Clash of Civilizations and the Remaking of World Order (New York: Simon \& Schuster, 1996).
} 
Demokratik veya liberal yönden olsun, ben demokratik kamusal alanda dini ilkelerin yasaklanması için ikna edici bir sebep göremiyorum. Birisi en fazla, "kilise" ve "devlet" arasındaki ayrılma ihtiyacını pragmatik tarihi planda savunabilir, ki ben tam ayrılığın demokrasi için ne gerekli ne de yeterli bir sebep olduğunu düşünüyorum artık. "Din" ve "siyaset" arasına bir ayırma duvarı kurma teşebbüsü hem temellendirilmemiştir, hem de muhtemelen demokrasi için ters tepecektir. "Dinin özgür yaşanmasının" kısıtlanması, kendiliğinden, dindar vatandaşların siyasi ve sivil haklarının özgür kullanımının kısıtlanmasına ve sonunda demokratik sivil toplumun hayatiyetine engel olacaktır. Belli başlı dini tartışmalar veya uygulamalar hukuki yasaklar anlamında demokratik ve liberal bir düzlemde belki eleştirilebilir veya sorgulanabilir, fakat sadece "dini" olduklarından dolayı değil.

Tocqueville, sekülerci ön yargılardan uzak ve göreceli bir berraklıkla bu konuları değerlendiren belki de biricik modern sosyal teorisyendi. O, Aydınlanmanın din eleştirisindeki iki ana çerçeveyi oluşturan, eğitim ve akıl yürütmenin yükselişi ile demokratik özgürlüklerin artışının dini siyaseten konu dışı bırakacağı önermelerini sorguladı. Oldukça öngörülü bir şekilde, siyasetin demokratikleşmesinin ve sıradan insanların siyaset alanına girişinin dinin kamusal bağını azaltmaktan ziyade artıracağını tahmin etti. Tocqueville, o zamanlar modern toplumların en demokratiği ve en yüksek seviyede okur yazarlığın olduğu Amerika Birleşik Devletleri'nin demokrasi hayatında tecrübi deliller buldu. ${ }^{31}$

Dünya genelindeki demokratik siyasetin tarihi, Tocqueville'nin öngörülerini doğrulamıştır. Dini konular, dini kaynaklar, mezhep içi çatışmalar ve seküler-dindar ayrılıklarının hepsi nispeten demokratik seçim siyasetinin ve demokrasi tarihi boyunca sivil toplum siyasetinin merkezini oluşturmuştur. Hatta seküler Avrupa'da, bireyselleşme tezinin, siyasi elitlerin ve sıradan insanların çoğunluğunu tarafından doğru olarak kabul gördüğü bu yerde, umulmadık bir biçimde, tartışmalı dini konular Avrupa siyasetinin merkezine tekrar geri döndü. ${ }^{32}$ Dolayısı ile aynı durumun Amerika Birleşik Devletleri'nde, tarihi olarak, dinin bütün önemli siyasi anlaşmazlıkların ve sosyal reform hareketlerinin her zaman tam merkezinde olduğu bu yerde, daha yüksek bir şekilde cereyan edeceğini söylemek şaşırtıcı olmamalı. Bağımsızlıktan ilgaya, yerlilikten kadınların oy kullanma hakkına, yasaklardan sivil hak hareketlerine kadar din bu anlaşmazlıkların daima merkezinde oluğu kadar, siyasi

\footnotetext{
${ }^{31}$ Tocqueville Kızılderililerin soykırımı ve siyah köleliğin sorunlarını tartışırken kaçamak davranıyor ve "onları demokrasi dışında oldukları" için Kitap 1'in sonunda ayrı bir bölüm içinde değerlendiriyor. Bu durum Amerika'nın sadece beyazlar için "irkçı" bir demokrasi olduğu ve böylece model bir demokrasi olmaktan çok uzak olduğu durumunun Tocqueville tarafından en azından zımnen farkında olunduğunu göstermektedir.

${ }^{32}$ José Casanova, "Religion, Secular Identities, and European Integration," Religion in an Expanding Europe, ed. Timothy Byrnes and Peter Katzenstein (Cambridge: Cambridge University Press, forthcoming).
} 
kamplaşmaların da her iki yanında olmuştur. Son birkaç on yıllık zaman zarfinda yeni olan, Amerikan siyasal tarihinde ilk defa çağdaş kültür savaşları, geçmişte Avrupa kıtası siyasetinde yaygın olan, seküler-dini ayrışımlara benzemeye başladı. Şimdi dinin kendisi ihtilaflı bir kamu sorunu halini ald.

Eğer bugün önceki çalışmalarımdaki herhangi bir şeyi gözden geçirmem gerekirse, bu, normatif gerekçelerle haklı olduğunu düşündüğüm, halk dinini sivil toplumdaki kamu alanına hasretme girişimim olur. Bu benim kendi kişisel normatif ve siyasal tercihim olarak duruyor, fakat dinin siyasal toplumdan veya hatta devletten seküler ayrışmasını demokratik siyasetin yeterli veya gerekli koşullarından biri olarak görmenin evrenselleştirilebilir düsturlar olması konusunda emin değilim. Sovyetler Birliği'nden seküler Türkiye'ye kadar birçok modern ve seküler olan otoriter ve totaliter devletlerin gösterdiği gibi, katı dini düzen yoksunluğu demokrasi için yeterli bir koşul anlamına gelmiyor. Diğer taraftan, İngiltere ve Lutheran İskandinav ülkeler gibi en azından sözde resmi devlet dini olan ülkeler, görece övgüye layık demokratik özgürlüklere ve dini olanlarını da içerir şekilde azınlık haklarını koruma geçmişine sahiptirler. Bu bakımdan katı bir ayrışmanın demokrasi için de gerekli bir koşul olmadığı görülüyor. Hatta bu önermeyi daha da ileriye taşıyarak, Amerikan Anayasa'sındaki ilk değişikteki iki cümleden biri olan "serbest ibadet" kendi başına normatif bir demokratik ilke olarak dururken, diğer hiçbir dini kurum ilkesinin sadece serbest ibadet ve eşit haklar konularında gerekli olduğu sürece savunulabilir olduğu düşüncesi önerilebilir. Diğer bir ifade ile, seküler prensipler kendi başına diğer zeminlerde savunulabilir, fakat özünde liberal demokratik olan bir konu olarak değil.

Dini çoğunlukların tiranlığından korunmak için geçerli olan kurallar, herhangi bir demokratik çoğunluğun tiranlığından korunmak için kullanılan demokratik kurallarla aynı olmalıdır. Dini veya seküler herhangi bir azınlığın haklarının korunması ve eşit evrensel erişim bütün liberal demokratik sistemlerin ana normatif ilkeleri olmalıdır. Prensipte, hiç kimse özel ek bir seküler ilke veya kanun maddesine ihtiyaç duymamalıdır. Fakat tarihi ve pragmatik olarak işin gerçeği, "kiliselerin" resmi statüsünü ilga etmek gerekli olabilir. Çünkü söylemek gerekirse, kiliseye bağlı dini kurumlar bir bölge üzerinde ya tekelci haklar iddia ederler ya da özel ayrıcalıklar isterler; veya anayasal ve bazen olağanüstü yöntemlerle kemikleşmiş çoğunluk tiranlarının gücünü azaltmak gerekli olabilir.

Son olarak, din ve ahlakın devam edeceği ve hatta demokratik siyasette daha fazla tartışmalı kamu konuları halini alacağını neden beklememiz gerektiğini gösteren ampirik düzeyde iyi argümanlar var. Artan evrenselleşme, ulus-ötesi göçler, çok kültürlülüğün çoğalması, bio-genetik evrim, cinsiyet ayrımcılığının ısrarlı devamı gibi eğilimlerden dolayı kamudaki tartışmalı dini meselelerin sayısının azalmaktan ziyade artması muhtemeldir. Sonuç, vatandaşın 
cumhuriyeti daha çeşitli ve parçalanmış hale geldikçe, kamu meselelerinin de artarak devam edeceğidir. En özeli de dahil olmak üzere, hayatın bütün alanlarına kamu düzeninin müdahalesi; insanlığa kendi kendini oluşturan ve yok eden yaratıcı güçler veren bilimsel-teknolojik keşiflerin artışı; bütün dünyanın tek bir ortak eve tüm insanlık için sıkıştırılması; ve çok kültürlülügü̈n özünde gözüken ahlaki çoğulculuk; bütün bu aşkın konular dinle irtibat halinde olmaya devam edecek ve dini cevapları kışkırtacaktır. 